\title{
Amadeus
}

International Multidisciplinary Journal ISSN 2525-8281

\section{Environmental licensing vs. Equitable and sustainable development: The incidence of the principle of proportionality as a weighing and choice instrument in the Brazilian judicial system}

Athena de Albuquerque Farias Maria Paula Silvestre Campelo

Francisca Ergovânia Batista de Brito $^{3}$

\begin{abstract}
The increase in the chances of potential environmental catastrophes due to excessive anthropic activity has caused society to turn its efforts to protect the environment. The notion of Sustainable Development was raised aiming economic growth based on the rational use of existing natural resources, for the purpose of preserving them for future generations. The concept of Equitable and Sustainable Development was created, which encompasses several aspects of society besides economic and environmental, with the main purpose of stimulate socially equitable development together with a sustainable environment. Environmental licensing consists of an administrative instrument used by the State to regulate potentially harmful activities to the environment. In this, it is sometimes necessary to consider constitutional principles, which requires verification of which should prevail, depending on the conflicting case. The present study defends the effectiveness of the use of the Principle of Proportionality in the act of weighing constitutionally protected interests, where the particularities of the concrete case must be analyzed in order to verify which institute should overlap, seeking the harmonization between free enterprise and the right to a balanced environment, these being the main principles involved in environmental licensing.
\end{abstract}

Keywords: Environmental Law. Administrative law. Sustainable Development. Environmental license. Principle of proportionality.

\footnotetext{
${ }^{1}$ Lawyer graduated from Centro Universitário dos Guararapes - UNIFG - PE, Brazil. Specialist in Procedural Labor Law by Faculdades Integradas de Cruzeiro - SP - Brazil. Master Student in Sustainable Development at the Università degli Studi di Milano. Contact: athena.farias@gmail.com;

2 Master in Education Sciences- University of Universidade Lusófona de Humanidades e Tecnologias - PT. paulascampelo@hotmail.com;

${ }^{3}$ Bachelor of Business Administration from Faculdade Leão Sampaio - FALS. Nurse at Leão Sampaio College - FLS. Specialist in Hospital Administration and Health Systems from the Regional University of Cariri - URCA. Specializing in Occupational Nursing- (EAD) -FIJ. Specializing in Public Policy and Public Health- URCA. ergovaniabrito@hotmail.com;
} 


\section{Introduction}

The constant advance in the relations of production and consumption has occasioned the amplification of the damages to the environment, such as the increase in the degradation of natural resources, pollution, socioeconomic inequality, as well as concentration of wealth.

As a result, in view of the potential generalized threat of catastrophes, it was necessary to stimulate the development of methods and techniques capable of guaranteeing economic growth and environmental preservation, in order to meet the productive and consumer needs without compromising environmental resources for future generations. Thus, the concept of Sustainable Development was born with the main objective to reduce the impacts caused to the environment by the increasing productivity and consumption.

Since that, it was noticed that was necessary to invest in a system capable of providing economic growth and reducing damages to nature, together with the control of political and socio-economic abuses, in order to enable a socially equitable and ecologically sustainable development (Rattner, 1999), which allowed the regulation of market relations, currently marked by inequality.

Thus, the concept of Equitable and Sustainable Development involves an approach that goes beyond the isolated analysis of technical and environmental aspects, requiring that historical and sociocultural concepts be considered. Its foundation is based on issues internal to society, social, cultural, personal identity, responsibility and solidarity, together with the impersonal mechanisms of economic activity, such as the market and the State, with a view to finding a formula that provides a balance between economic efficiency and social justice (Rattner, 1999).

Environmental licensing is a legal instrument closely related to sustainable development, with the aim of establishing a balance and harmonization between the Principle of Free Initiative (Principles of free competition and free initiative) and the Principles of Protection to the Environment (Environmental principles). As both principles are constitutional, there being a conflict between them, it is necessary to make a judgment weighing the interests involved in the specific case, in order to verify which one should prevail. 
In this context, the Principle of Proportionality, which governs the Brazilian Public Administration, is a true ally of social equity, since it obliges the Administration to consider its action depending on the case in question, serving also as an institute of legitimacy of the State activity, since it imposes that the means used are capable of justifying the ends sought by the administrative act carried out, so that the Administration can not act to benefit or harm any particular.

On the basis of this, this article defends the importance of the Principle of Proportionality for Environmental Law, since it is a useful and effective method to carry out the balancing of conflicting interests in the context of an environmental licensing process, including the fact that State intervention in property, as well as individual freedom, can not take place arbitrarily or unequally, otherwise it may cause excessive damage to the individual rights.

\section{Brief considerations on equitable and sustainable development and their relevance nowadays}

The Sustainable Development consists of a model that aims to encourage society as a whole to seek solutions to problems that currently harms the environment caused by anthropic activity, especially the indiscriminate exploitation of natural resources and the pollution of nature, with the focus of enabling the next generations enjoy a healthy and balanced environment. The constitutional right to the balanced environment constitutes a fundamental right of collective ownership, as the Federal Supreme Court of Brazil has already ruled:

The right to environmental integrity - typical third-generation law - is a legal prerogative of collective ownership, reflecting, within the process of affirmation of human rights, the significant expression of a power attributed, not to the individual identified in its uniqueness, in a truly broader sense, to the social collectivity itself. (Brazil. Federal Supreme Court. Security Order No. 22.164, Rel. Min. Celso de Mello, judgment on 10-30-1995, Plenary, DJ of 17-11-1995).

In 1980, the term was first used in the World Conservation Strategy, developed by the World Conservation Union (IUCN) in conjunction with the World Wildlife Fund (WWF), but only in the Blundtland ${ }^{1}$ Report (1991) was used more broadly to refers to a process that aims at modifying the current form of exploitation and use of natural resources and technological development, encouraging institutions to harmonize their way of acting in order to improve the productive capacity of the present, preserving the 
environment, as well as the productive potential of the future (Pereira; Chiari; Accioly, 2010, p.4). In addition, the document defined three main goals to be achieved with Sustainable Development: economic development, environmental protection and social equity.

As Robert Costanza (1991) teaches, the concept must analyze the dynamics between the interaction of the human economic system and the ecological system, taking into consideration that the former has a potential for modification and adaptation greater than the second. In this scenario, for this relationship to be sustainable, it is fundamental that human life acts and develops respecting the limits established by nature so that it does not cause damage to the ecological system.

With this, Sustainable Development has become synonymous with the need to formulate appropriate policies to make possible the use of natural resources, without causing them exhaustion, as a means of making economic development feasible, together with preservation of the environment. In addition, it implemented in society the idea that all are equally responsible for the preservation of nature ${ }^{2}$, following what is provided for in Article $225^{3}$ of the Brazilian Constitution of 1988, transforming this environmental issue into a political agenda (Rodrigues, 2005).

Within this framework, Equitable and Sustainable Development has emerged ${ }^{4}$, whose new approach requires the incorporation of several dimensions and social indicators, establishing a systematic between social, political, environmental and cultural aspects, among others; with the goal of enabling the process of economic development and environmental preservation, without neglecting other sectors of society.

Thus, it is noted that the implementation of the concept, aims to stimulate the formulation of policies capable of regulating the use of environmental wealth, which is capable of meeting the productive needs of society, without harming nature, and, to overcome the obstacles of historical injustices, social disparities and economic inefficiencies, and finally, the reduction of the existing socioeconomic differences.

\section{Principle of proportionality}

The Public Administration is governed by a normative framework that governs its activity, guide and regulates its actions. In this set of norms, there are the administrative principles, which are the basis of all administrative activity, among which is the principle 
of Proportionality, being this institute common in several jurisdictions, such as the European Union and Brazil.

In the European Union, this principle aims to measure the performance of the Administration, which must act in an appropriate manner, without committing excesses in the attempt to carry out its attributions, expressing a way of adapting the community resources in the pursuit of its objectives. It is complemented by the principle of Subsidiarity, which is intended to limit negatively the performance of the European Union in favor of the Member States, by determining that the Member States may exercise competing competences as long as the Community institutions do not demonstrate that their form of operation will be more effective (Lapointe, 1994, page 446, Lima Filho, 2006, page 13, Tables, 2013, p 104).

In Brazil, as taught by José dos Santos Carvalho Filho (2015, page 43), the principle of Proportionality focuses on Administrative Law as a mechanism for limiting and controlling state activity, with the main objective of avoiding excess power. The author emphasizes, however, that the application of the principle can not interfere in the margin of discretion that the Administration holds in certain legally defined situations. In Brazilian Administrative Law, the Principle of Reasonability presents itself as an accessory to this principle, being the reasonable action related to the administrative performance within limits of acceptability.

Hely Lopes de Meirelles (2007, p 102), comments that this principle is also known as the Principle of Prohibition of Excess, as it seeks to avoid unnecessary or excessive restrictions on the part of the Administration, that are capable of causing injury to the individual rights of the means and the ends of administrative acts. This position is the same one issued by Celso Antônio Bandeira de Mello (2007, p.110) when it states that "administrative competences can only be validly exercised in the extent and intensity proportional to what is really demanded for the fulfillment of the public interest purpose which are linked ".

Given that, analyzing the Principle of Proportionality - and its complementary ones - applied by the European Union and the one used by the Administrative Law of Brazil, it is noted that both are to limit the state's performance in different ways, real constituting instruments of control of possible abusive acts. 


\section{The use of the principle of proportionality as a method of weighing conflicting interests in environmental licensing in Brazil}

The need for a sustainable development in order to obtain a healthier and more balanced environment made essential the intervention of the State in the economic domain, which needed to use Police Power $^{5}$ to regulate potentially polluting economic activities $^{6}$.

Thus, environmental licensing is used as a regulatory and control instrument for potentially polluting economic activities, in which the Administration imposes limits to the exercise of economic activities, with the use of prior control and supervision of its facilities and mode of operation (Bevilaqua, Salvador apud Benjamin, 2005, pp. 522523). The main objective is to ensure the conscious exploitation of the natural resources and the means of production used, so that can not be harmful to the environment, without however, makes it impossible to exercise the economic activity itself.

In order to do so, this instrument, - widely mentioned by the doctrine as one of the main tools to guarantee Sustainable Development (Farias, 2007, p.367), establishes several conditions for the authorization of economic activities, with the environmental license being the product resulting from an administrative procedure which, in the end, may be embodied in a positive administrative act represented by the issue of a license (Santos, 2001, p.84).

Thus, the license is a tied administrative act, which gives the individual the subjective right to carry out the required activity, provided that the legal requirements are met. In addition, it is an act originating from the Police Power, since it involves a restriction of freedom, issued when the individual complies with all the legally required requirements for the exercise of a given activity, proving to have adopted the necessary measures to mitigate damages to the environment or compensation to them (Magalhães, Vasconcelos, 2010, p 246).

Paulo Affonso Leme Machado (2008: 332), refers to this situation as the Power of Environmental Police ${ }^{7}$, because it involves State activity that limits individual rights, interests or freedom; specifically aimed at regulating the practice of acts concerning population health, conservation of the environment, the exercise of economic activities, etc.; whose activities could cause harm to the environment. 
As emphasized by Minister Celso de Mello, in his vote in ADI (Direct Action of Unconstitutionality) n. 3.540-MC ${ }^{8}$, the main guiding principles of Environmental Law are antagonistic, because on the one hand there is the defense of free initiative and, on the other, there is the imposition of the preservation of nature. Knowing that both rights are protected by the Brazilian Constitution of 1988 , it shows that it is necessary to carry out a concrete consideration in order to harmonize the conflicts or verify which should prevail ${ }^{9}$, the main aim being to obtain a balance between the development of the economy and the environmental preservation.

On that basis, the Proportionality Principle presents itself as an interesting method for the realization of this weighting between conflicting constitutional principles, in which a balance must be present, that emphasizes the minimum state intervention in individual freedoms, without this implying emptying of any of the principles. When applied, the principle must be analyzed on the basis of three subprinciples, namely: (i) adequacy, which verifies whether the means used are adequate for the intended purpose, (ii) the necessity or the prohibition of excess, which aims to the least possible State intervention; and (iii) proportionality stricto sensu (balancing), which analyzes the burden imposed and the benefit brought by the administrative measure (Barroso, 1993, p.209).

The sub-principles should be analyzed in the sequence set out above, so that the necessity analysis only occurs if it is found that the means adopted by the Administration are adequate, and therefore, the proportionality analysis itself should be initiated only if the least damaging measure was used to the interest of the individual (Silva, 2002, p.35).

Thus, it is clear that environmental licensing is not just an instrument of environmental protection, which must at all costs impose environmental protection to the detriment of economic development, especially since the restrictions on fundamental rights must be exceptional and dependent on the case under analysis, to be applied only if it is not possible to adopt a less onerous measure for the individual.

In this sense, knowing that there is no absolute fundamental right, as well as that there is no hierarchy among constitutional principles, will be the details of the concrete case presented in the context of an environmental license process, which will provide the necessary theoretical basis for reaching a decision ${ }^{10}$, leaving to the Principle of Proportionality the requirement of protection to the environment, without this meaning the emptying of constitutional economic freedoms, and vice-versa. 
The application of the Principle of Proportionality in this type of environmental process has occurred in the Brazilian Courts, as can be verified in the following jurisprudence:

\begin{abstract}
ADMINISTRATIVE AND CIVIL PROCEDURE. INTERNAL RULING IN THE SPECIAL APPEAL. PUBLIC CIVIL ACTION. OCCUPATION AND BUILDING IN A PERMANENT PRESERVATION AREA, NEAR THE IVINHEMA RIVER. VEGETATION SUPPRESSION. CONCESSION OF ADMINISTRATIVE LICENSE. RECOGNIZED ILLEGALITY, BY COURT OF ORIGIN. INAPPLICABILITY OF THE THEORY OF THE CONSUMED FACT, IN THE MATTER OF ENVIRONMENTAL LAW. DOMINANT JURISPRUDENCE OF THE SUPREME COURT. VIOLATION OF THE PRINCIPLE OF COLLEGIALITY. NO OCCURRENCE. PRECEDENT 568 / STJ AND ART. 255, § $4^{\circ}$, III, DO RISTJ. DUTY OF REPAIR OF THE AGENT CAUSING ENVIRONMENTAL DAMAGE. PRECEDENTS OF THE SUPREME COURT, IN IDENTICAL CASES. INTERNAL RULING IMPROVED. (...) III. The Court of origin, despite recognizing the existence of buildings, in a permanent preservation area, with suppression of vegetation, in violation of environmental legislation, as well as the illegality of the authorization granted, reformed the sentence, to dismiss the action, under the that the situation is consolidated, due to a previous license granted by the Institute of the Environment of Mato Grosso do Sul - IMASUL, thus, it was not possible to apply the measures of vacate, demolition of buildings and reforestation of the area, determined by the sentence, under penalty of offense to the principles of reasonableness and proportionality. (...) VII. Since the judgment appealed in disagreement with the present and dominant understanding of this Court, the decision now aggravated should be upheld, which upheld the Special Appeal of the Public Prosecution Service of Mato Grosso do Sul, in order to reinstate the sentence, which found the present Public Civil Action partially valid. VIII. Unappealable internal ruling. (BRAZIL, SUPREME COURT, Internal Injunction In The Embargo Of Declaration In The Appeal In Special Appeal 2013 / 0194911-4, Minister Assusete Magalhães, Third Class, 07/12/2017, emphasis added).
\end{abstract}

Thus, it is believed that the Proportionality Principle is a valuable instrument for the assessment of the possibility of applying restrictions to some fundamental right, since it establishes intersubjectively controllable criteria to be used in the weighting of conflicting constitutional interests (Sarmento, 2010, p. 156), revealing importance and utility for the environmental license because it is a weighing method that requires consideration of the particularities of the case under discussion, which makes the decision fair and with less margin of error.

\title{
Final considerations
}

Sustainable Equitable Development consists of the search for harmonious and egalitarian economic growth, which promotes productivity growth, with the lowest possible impact on nature and that aims the reducing social inequalities, so that the satisfaction of the present needs of the population does not compromise the existing 
natural resources in the future. For this reason, it is a model that must take into consideration diverse aspects inherent to society itself, beyond the productive need of society and imposition of environmental preservation, such as culture, political particularities, socioeconomic characteristics, among others.

The persevering pursuit of the implementation of Sustainable Development in Brazil, made the State's intervention in the economy and in property necessary and legitimate, with a focus on guaranteeing environmental protection. To this end, the State began to use mechanisms that limit human activity, capable of interfering negatively with individual rights, even if constitutionally consecrated.

Among the tools of limitation of individual rights used by the Public Administration, it is the environmental license, being this document granted after complying with legally defined requirements, which are considered indispensable for the exercise of an activity potentially harmful to the environment, such as to be carried out in the least damaging way possible to nature. However, the instrument should also imply the least restrictive restriction on the right to free enterprise, since it is as important as the constitutional imposition of environmental protection and preservation.

However, the State's duty to defend and preserve the environment is not enough to justify unreasonable limitations on individual rights, and the other principles and interests involved in the specific case must be taken into account. Furthermore, environmental licensing can not set an end in itself, as it is directly related to the public purpose for which it was created, and this is the incentive for Sustainable Development that results from the harmonization between the development of the economy and also the environmental protection.

Thus, the use of the Principle of Proportionality in environmental licensing is effective for the analysis and weighing of the constitutional rights involved in the process. Moreover, it is a method that fosters social equity, since it requires that the Public Administration act observing the legislation and the details of the concrete case, and must demonstrate that means justify the purposes intended by the deference or not of the environmental license, which prevents them from acting in a biased way to benefit or harm those administered. 


\section{Notes:}

${ }^{1}$ It is a document prepared by the World Commission on Environment and Development (WCED), which defines important terms related to sustainable development. According to the report, sustainable development consists of a technique capable of meeting the needs of present generations without compromising the possibilities of future generations, allowing them to have sufficient resources to meet their own needs (World Commission on Environment and Development, 1987).

2 According to Sidarta Ruthes and Décio Estevão Nascimento (2006), development must be systematic, so that it must be carried out in a collective and participative way, which allows the presence of significant effects in the promotion of sustainability.

${ }^{3}$ Article 225. Everyone has the right to an ecologically balanced environment, a common use of the people and essential to a healthy quality of life, imposing on the public power and the community the duty to defend and preserve it for the present and future generations.

${ }^{4}$ In 1986, at the Ottawa Conference, the notion of Sustainable and Equitable Development was presented as a new paradigm, whose main objectives were defined as: (i) conservation of nature; (Ii) satisfaction of basic human needs; (iii) equity and social justice; (iv) social self-determination and cultural diversity; (v) maintenance of ecological integrity (Montibeller filho, 1993, p.135).

${ }^{5}$ Regarding the Police Power, it is worth mentioning that this consists of "state activity of conditioning freedom and property by adjusting them to collective interests (...). It refers, therefore, to the complex of measures of the State that delineates the legally protected sphere of freedom and property of citizens (Bandeira de Mello, 2008, p.780).

${ }^{6}$ It should be pointed out that the Police Power in this case must result in the least possible intervention of the State in the economy and property, since the exercise of political power can not eliminate the necessary space for the administrative to enjoy their individual freedoms (Sundfeld , 2003, page 67).

7 The Supreme Court of Brazil recognized the legitimacy of the Power of Environmental Police in the ADPF judgment n. 101, led by the Minister-Rapporteur Carmen Lúcia. In judging the aforementioned constitutional remedy, the Court carried out a consideration of constitutional principles, in which it denied protection of the right to free initiative, in favor of the rights to protect the environment and health (BRASIL, STF, ADPF 101/2009, Min. Rapporteur Carmen Lúcia, Full Court, 06/24/2009).

${ }^{8}$ BRASIL, STF, ADI n. 3.540-MC, Ministro-Relator Celso de Mello, 03/02/2006.

${ }^{9}$ Robert Alexy (2008, p. 93) teaches that, in the face of a collision of principles, one institute will have to yield to the other, depending on the conditions involved in the particular case in question.

${ }^{10}$ According to Robert Alexy's $(2008,297)$ teachings, there are two theories about the intangible core of fundamental law: (i) an absolute, which holds that every fundamental right has an unattainable core; and (ii) a relative one, which understands about the existence of an essential nucleus, which can be overlapping once the Principle of Proportionality is observed.

\section{References}

Alexy, Robert (2008). Teoria dos Direitos Fundamentais. Tradução por Virgílio Afonso da Silva. São Paulo: Malheiros.

Barroso, Luís Roberto (1993). Proteção do Meio Ambiente na Constituição Brasileira. Revista Trimestral de Direito Público, São Paulo: Malheiros. 
Bevilaqua, Carlos Augusto Silva; Salvador, Vitor Henrique (2005). Satanização do licenciamento ambiental. Benjamin, Antônio Herman de Vasconcellos (org). Paisagem, natureza e direito. Vol. 2. São Paulo: Instituto O Direito por um Planeta Verde.

Camargo, Diógenes Rafael de (2016). Os conceitos de sustentabilidade e de desenvolvimento sustentável na produção teórica em educação ambiental no brasil: um estudo a partir de teses e dissertações. Dissertação (Mestrado em Educação), Rio Claro, Universidade Estadual Paulista.

Carvalho Filho, José dos Santos (2015). Manual de Direito Administrativo. São Paulo: Atlas, 2015.

Castro, Fabio de; Hogenboom, Barbara; Baud, Michiel (2011). Governança ambiental na América Latina: para uma agenda de pesquisa mais integrada. Ambiente \& Sociedade, v.14, n.2, São Paulo, Jul/Dec.

Costanza, Robert (1991). Ecological economics: the science and management of sustainability. New York: Columbia Press.

Farias, Taldem (2007). Licenciamento Ambiental: aspectos teóricos e práticos. Belo Horizonte: Fórum.

Feitosa, Isabelle Ramos; Lima, Luciana Santana; Fagundes, Roberta Lins (2004). Manual de Licenciamento Ambiental: guia de procedimento passo a passo. Rio de Janeiro: GMA.

Fiorillo, Celso Antônio Pacheco; Morita, Dione Mari; Ferreira, Paulo (2015). Licenciamento Ambiental. 2. Ed. São Paulo: Saraiva.

Lapointe, Benoît (1994). "Le principe de subsidiarité sous l'éclairage de l'enseignement social de l'église: limitation ou extension des compétences de la communauté européenne?". In: L'identité politique. Paris: PUF.

Lima Filho, Francisco das C. (2006). A ordem jurídica comunitária Europeia: princípios e fontes. Revista Jurídica UNIGRAN. Dourados, v. 8, n. 15, Jan/Jun.

Machado, Paulo Affonso Leme (2008). Direito Ambiental Brasileiro. 17. ed. São Paulo: Malheiros.

Magalhães, Gustavo Alexandre; Vasconcelos, Luis André de Araújo (2010). O licenciamento ambiental à luz do princípio constitucional da proporcionalidade. Veredas do Direito, Belo Horizonte, v.7, n.13/14, p.241-268, Jan/Dez.

Meirelles, Hely Lopes de (2007). Direito Administrativo Brasileiro. 33ed. São Paulo: Malheiros.

Mello, Celso Antônio Bandeira (2008). Curso de Direito Administrativo. 25ed. São Paulo: Malheiros.

Montibeller Filho, Gilberto (1993). Ecodesenvolvimento e desenvolvimento sustentável. Textos de Economia. Florianópolis, v. 4, a. 1, p. 131-142. 
Pereira, Maria de Lourdes Dolabela; Chiari, Pereira Mirna; Lima; Sabrina Maria de Lima Accioly (2010). As Dimensões da Sustentabilidade e suas Possibilidades de Utilização nas Políticas Públicas. Anais... V ENANPPAS, v. 6.

Quadros, Fausto de (2013). Direito da União Europeia: Direito Constitucional e Administrativo da União Europeia. $3^{\text {a }}$ ed. Coimbra: Almedina.

Quadros, Fausto de (1995). O princípio da subsidiariedade no direito comunitário após o Tratado da União Europeia. Coimbra: Livraria Almedina.

Rattner, Henrique (1999). Sustentabilidade - uma visão humanista. Ambiente \& Sociedade, Campinas, n. 5, Jul/Dec.

Rodrigues, Arlete Moysés (2005). Problemática Ambiental. Agenda Política, Espaço, Território, Classes Sociais. Boletim Paulista de Geografia, São Paulo, n. 83, p. 91-110.

Ruthes, Sidarta; Nascimento, Décio Estevão (2006). Desenvolvimento Sustentável e os Arranjos Produtivos Locais. In: Simpósio de Administração da Produção, Logística e Operações Internacionais, 9, 2006, São Paulo. Anais... do IX SIMPOI. São Paulo: FGV/EAESP.

Sarmento, Daniel (2010). Direitos Fundamentais e Relações Privadas. 2. ed. Rio de Janeiro: Lúmen juris.

Silva, Luis Virgílio Afonso da (2002). O Proporcional e o Razoável. Revista dos Tribunais, n. 798, abr.

Sirvinskas, Luís Paulo (2018). Manual de Direito Ambiental.16. ed. São Paulo: Saraiva Educação.

Sundfeld, Carlos Ari (2003). Direito Administrativo Ordenador. São Paulo: Malheiros.

World Commission on Environment and Development (1987). Our common future. Oxford: Oxford University Press.

\section{How to cite this article (APA format):}

Farias, Athena de Albuquerque; Campelo, Maria Paula Silvestre; Brito, Francisca Ergovânia Batista de. (2019). Environmental licensing vs. Equitable and sustainable development: The incidence of the principle of proportionality as a weighing and choice instrument in the Brazilian judicial system. Am. In. Mult. J., October. (7) 4, 1-12.

Received: 07/04/2019

Accepted: 08/03/2019 